昭和大学病院職員における 治験に関するアンケート調査 その 1 一全体像一

井口佳子、俵積田ゆかり、日比野文代、鈴木佐智子 岩松みつ子、鹿嶋紘子、川村芳江、嶋村暁子 小坂朋子、内田英二

【目的】新 GCP 施行から 5 年が経過し、今後の臨床試験 （治験）体制のあり方を検討することを目的に、病院職員 の意識調查を行った。アンケート結果を解析し、臨床試験 支援部門としての今後の課題を検討した。

【方法】治験に関連する各部署（診療科・看護部・薬剂部・ 検査部門・事務部）の職員 440 名を対象に文書によるアン ケート調査を実施した。調査期間は 2003 年 7 月 9 日〜 7 月 28 日、配布方法は各部署の責任者を介して行い、回答 者の選定は責任者に一任した。調查内容は治験の意識・理 解に関することを中心に、32 項目の質問を作成した。

【結果】回収数は 341 件、回収率は $77.5 \%$ あった。 Fig.1に示すように、職員の治験に対する認識は高かった。 「当院で治験を実施していること」に関しては、聞いたこ とがある」を含めると $95 \%$ 職員が知っているとの回答で あった。一方で、実施されている具体的治験（Fig.2）につ いての認識は低く、医療機関側の契約者について「知らな い」が $45 \%$ 、治験支援部署の存在や活動についても「知ら ない」が $25 \%$ 存在した。

\section{Fig.2 当院で実施している具体的治験}

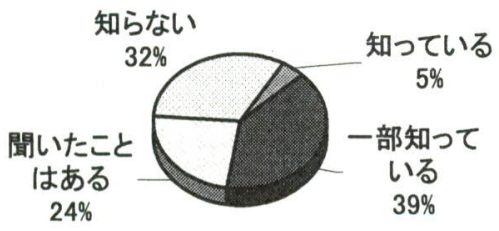

Fig.1 治験とは何か知っているか

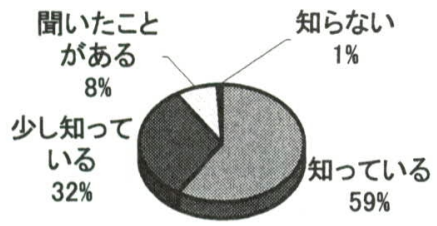

昭和大学病院臨床試験支援センター

干 142-8666 東京都品川区旗の台 1-5-8
アンケートに答えた職員の $56 \%$ が、実際に治験患者の対応 を経験していた。しかし、治験に関する院内ポスターにつ いて「知らない」が $32 \%$ 、治験患者専用ダイアルは $78 \%$ の 職員が「知らない」と答えた。

次に、職員の治験業務に対する意識や、勉強会等に関する 意欲についての結果を Fig.3.4 に示す。治験業務の依頼に 関する「その他」の意見には、「内容による」「出来る範囲 で協力する」「わからない」などが挙げられた。

\section{Fig.3 治験業務を依頼されたら}

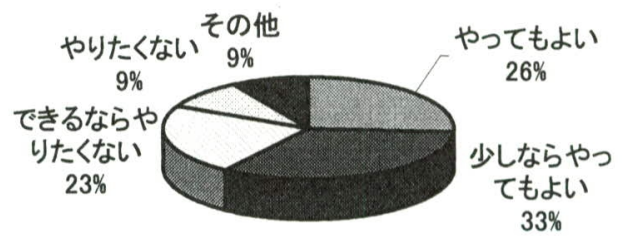

Fig.4 勉強会を開催した場合参加するか

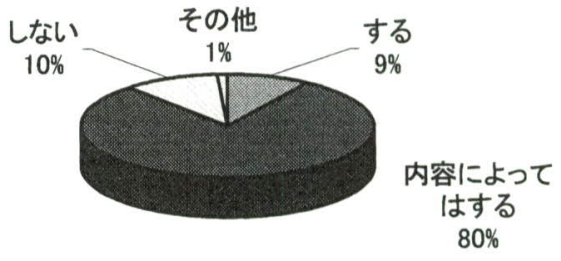

【考察】今回のアンケート結果から、治験に関する基本的 内容が職員に浸透していない現状が浮彫りになった。しか し、勉強会等の参加に対しては「内容によっては参加する」 との回答が多く、テーマや対象者の選定などの企画立案が 重要であると考える。また、治験業務の依頼については半 数以上が協力的姿勢を示しており、臨床試験支援部門とし て、職員の意欲を高め維持していく方法を検討し提示して いく必要があると再認識できた。

治験の実施に関わっている職員は限定されるため、具体的 治験の内容についての認識が低いことは予想された。しか し、院内ポスターや患者専用ダイアル・治験支援部署の活 動に対する認識が低く、今後は職員へのアピールや伝達方 法を見直し、工夫していく必要があると考える。

【まとめ】

1. 診療の一部として治験を捉え、被験者を医療機関全体 でサポートするという意識を育てる関わり (教育) が必要 である。

2. 臨床試験を支援する部門として、新薬開発に対する医 療機関の役割と、治験の意義について啓発する具体的活動 が重要である。 